\title{
USULAN PERBAIKAN PERANCANGAN PRODUK SEPATU PERAWAT DENGAN PENDEKATAN METODE QUALITY FUNCTION DEPLOYMENT(QFD)
}

\author{
Dewi Shofi Mulyati ${ }^{1}$, Nugraha ${ }^{2}$, Iyan Bachtiar ${ }^{3}$ \\ Jurusan Teknik Industri, Fakultas Teknik, Universitas Islam Bandung ${ }^{1,2,3)}$, \\ Jawa Barat, Bandung \\ E-mail :dewishofi@gmail.com ${ }^{1}$, nugraha692004@yahoo.com²,iyanbachtiar1806@gmail.com ${ }^{3}$
}

\begin{abstract}
Shoes are footwears needed by everyone such as employees, housewives, students or any other profession to do their activity. One example of profession that wears shoes in doing their work is a nurse in the hospital. An intial observation done to the nurse profession in the hospital shows that there is a problem in the condition of the shoes they wear. The shoes condition is not suitable to the characterisctic of the work, as well as to the condition of the workplace enviroment, which could lead to fatigue to the nurses and significantly influence the stress level of the nurses. The study aims to design a shoes that meet the the consumers wishes and the ergonomic value which eventually could be proposed as the improvement design for the nurse shoes. The method used in this study is Quality Function Deployment (QFD) as a design method used to determine the priority needs and desires of consumers, as well as to classify them. From the data processing and analysing, it is shown that the innovation made in the shoes for nurses are on the material used, which previously used a cow skin and now it uses velvet, in order to reduce the production cost; the heel design of the shoes which is modified to be more varies to meet the nurse needs; the replacement on the soles materials so they would not be slippery and they would cost less.
\end{abstract}

Keywords : Shoes Design; Quality Function Deployment (QFD); House of Quality (HOQ).

\section{PENDAHULUAN}

Sepatu merupakan salah satu jenis alas kaki yang diperlukan untuk beraktifitas oleh semua orang, baik itu karyawan, ibu rumah tangga, mahasiswa, pelajar atau profesi lainnya. Perawat merupakan pengguna sepatu yang bekerja di Rumah sakit. Perawat juga merupakan salah satu tenaga medis yang memberikan pelayanan medis kepada masyarakat untuk menunjang kesembuhan pasien.

Karakteristik beban pekerjaan perawat yang berupa beban kerja fisik dan mental dapat berpeluang besar untuk membangkitkan stres. Seorang perawat dituntut untuk meningkatkan kualitas pelayanan kesehatan kepada masyarakat. Oleh karena itu perawat dituntut untuk lebih profesional agar kualitas pelayanan yang diberikan semakin meningkat kepada masyarakat.
Dari pengamatan yang dilakukan terhadap pekerjaan perawat khususnya di rumah sakit, teramati bahwa mobilitas perawat sangat dominan pengaruhnya dalam menentukan kepuasan konsumen, respon fisik mengambarkan reaksi perawat terhadap permintaan konsumen. Berdasarkan pengamatan, salah satu hal yang berpengaruh terhadap mobilitas perawat adalah jenis dan kondisi sepatu yang mereka gunakan. Sepatu yang tidak sesuai dengan karakteristik pekerjaan perawat dan kondisi lingkungan tempat kerja mengakibatkan kelelahan kepada perawat, yang pada akhirnya akan berpengaruh secara signifikan pada tingkat stres perawat, oleh sebab itu maka kami memandang perlu untuk dilakukan perancangan sepatu perawat yang dalam hal ini kami akan memgambil kasus pada sepatu perawat wanita. 


\subsection{Perumusan Masalah}

Dari latar belakang tersebut maka dapat diambil beberapa pokok permasalahan diantaranya :

1. Produk sepatu perawat wanita yang ada belum memberikan kenyamanan yang prima untuk seorang perawat.

2. Terdapat perawat yang masih menggunakan alas kaki yang belum memenuhi standar kesehatan dan estetika (beberapa masih menggunakan sandal dalam bertugas).

3. Bagaimana menciptakan rancangan produk sepatu perawat yang nyaman, aman dan mengikuti perkembangan fashion. Penelitian ini dimaksudkan untuk memperbaiki rancangan proses pembuatan produk sepatu perawat wanita dengan memenuhi kriteria nyaman, aman serta fashionable yang sesuai dengan keinginan konsumen.

\subsection{Tujuan Penelitian}

Tujuan penelitian ini adalah :

a. Perbaikan perencanaan produk sepatu.

b. Perbaikan perencanaan komponen sepatu.

c. Perbaikan perencanaan proses pembuatan sepatu.

d. Perbaikan pencanaan produksi pembuatan sepatu.

\section{KAJIAN LITERATUR}

Konsep Qualty Function Deployment merupakan alat untuk mengidentifikasikan kebutuhan pelanggan. Tujuannya adalah menjamin bahwa produk yang dihasilkan dapat memenuhi tingkat kualitas yang memuaskan pelanggan. Salah satu bentuk penilaian kinerja industri adalah penilaian terhadap Quality Function Deployment (QFD). Sulistyawati (2005:86) mengungkapkan bahwa penelitian menggunakan QFD mampu mengungkap kesenjangan kualitas produk dan layanan dengan fakta yang diterima pelanggan sehingga perlu dilakukan tindakan teknis peningkatan sumber daya manusia dan manajemen.
Metode QFD bertujuan untuk
pengembangan produk yang dapat memuaskan konsumen dengan menerjemahkan keinginan konsumen ke dalam karakteristik mutu yang menjadi sasaran desain dan elemen pengendalian mutu untuk digunakan diseluruh proses produksi. Kemampuan menghasilkan produk sesuai dengan kebutuhan dan keinginan konsumen merupakan faktor kunci yang harus dimiliki oleh perusahaan untuk dapat menghasilkan produk yang berdaya saing tinggi.

Quality Function Deployment (QFD) merupakan suatu metode yang digunakan untuk menentukan prioritas kebutuhan dan keinginan konsumen serta mengelompokannya. QFD dapat digunakan baik pada perusahaan yang menawarkan produk ataupun jasa bagi konsumen.

\section{METODE PENELITIAN}

Adapun langkah - langkah yang digunakan dalam penelitian ini dilihat dalam flowchart pada gambar 1 .

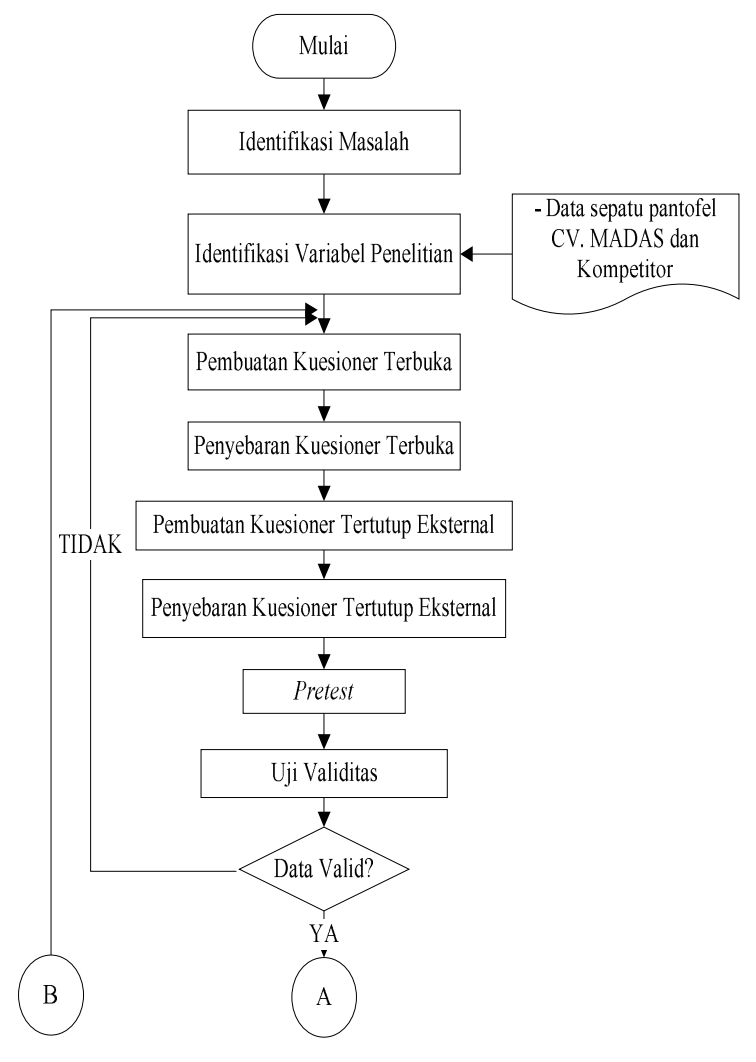




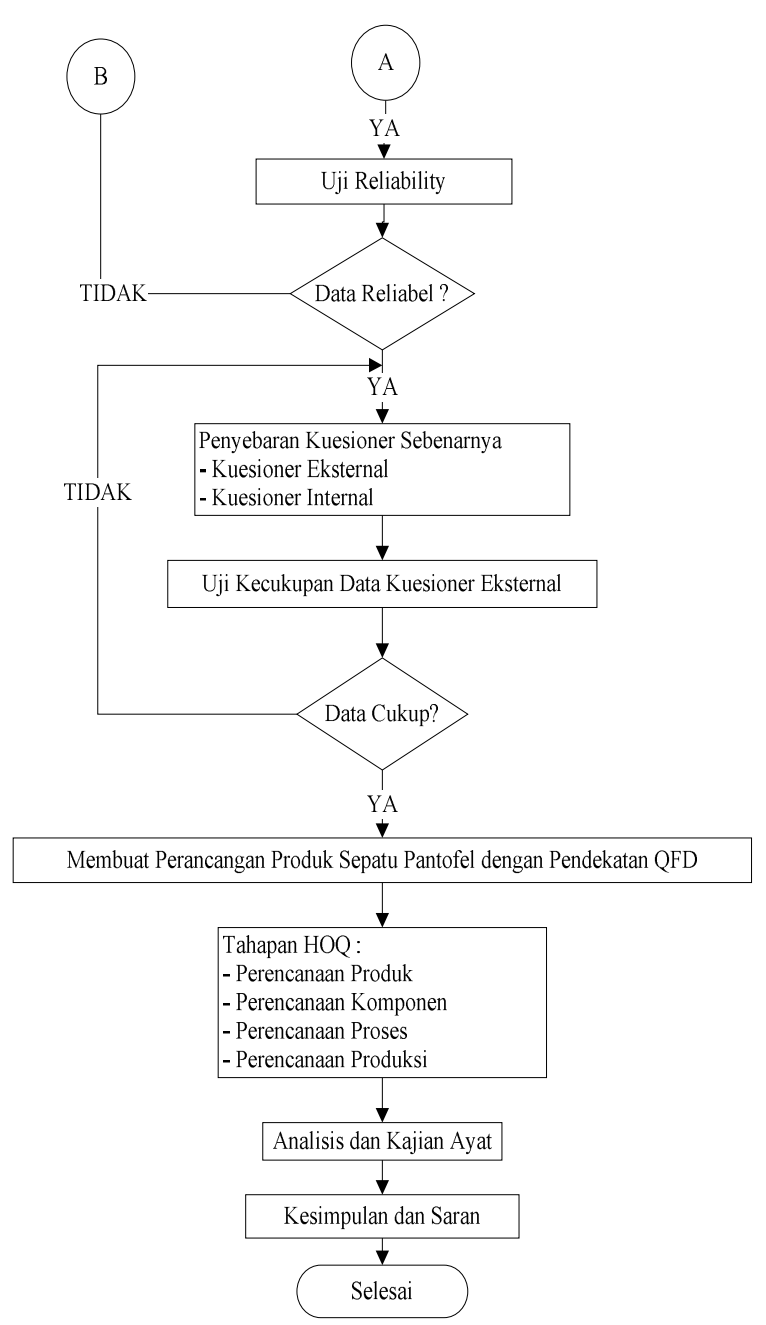

Gambar 1. Metode Penelitian.

\section{HASIL DAN PEMBAHASAN}

\subsection{Pengumpulan Suara Pelanggan (Voices of Customer)}

Pada proses ini dilakukan dengan menggunakan kuesioner terbuka. Hal ini dilakukan agar suara pelanggan dalam hal ini perawat mengenai sepatu yang digunakan saat bertugas dapat tersampaikan. Responden pada penelitian ini lebih difokuskan pada perawat menengah ke bawah.

\subsection{Pengumpulan Data}

Pengumpulan data dalam penelitian ini dimulai dari identifikasi variabel penelitian, penentuan alat ukur penelitian, pembuatan kuesioner, penentuan jumlah sampel penelitian, penyebaran kuesioner pretest hingga diperoleh data hasil penyebaran kuesioner pretest.
Dari hasil penyebaran kuesioner terbuka diperoleh 6 buah variabel eksternal yang menjadi kebutuhan dan keinginan konsumen terhadap sepatu perawat. 1) Performansi (performance) 2) Features 3) Keandalan (Reliability) 4) Konformasi (conformance) 5) Durability 6) Estetika. Sedangkan variabel internal ada 8 buah variabel internal yaitu : 1) Biaya produksi 2) Bentuk hak , 3) Jenis bahan berkaitan 4) Karakteristik bahan 5) Perencanaan produk , 6) Proses produksi, 7) Pemasaran, 8) Keindahan produk.

\subsection{Pengolahan Data}

\subsubsection{Pembuatan Matriks Perencanaan Produk (Product Planning)}

Proses pembuatan matriks perencanaan produk ini dilakukan melalui 7 langkah yaitu $:$ :

1. Daftar Kebutuhan dan Keinginan Konsumen (WHATs). Berisikan data atau informasi yang diperoleh dari hasil penyebaran kuesioner eksternal tentang kebutuhan dan keinginan konsumen (pelanggan).

2. Deskripsi Teknis $(H O W s)$, Berikut ini adalah daftar deskripsi teknis yang terdapat dalam matriks perencanaan produk (Product Planning), deskripsi teknis ini diperoleh sebanyak 8 variabel, yaitu : biaya produksi, bentuk hak, jenis bahan, karakteristik bahan, perancangan produk, proses produksi, pemasaran dan keindahan produk.

3. Matriks Hubungan Antara WHATs dan HOWs. Adapun kriteria penentuan matriks hubungan antara persyaratan pelanggan (What's) dengan deskripsi teknis (How's) adalah :

a. Hubungan yang kuat itu terjadi antara harga Rp. 110.000 - Rp. 150.000 dengan biaya produksi. Hubungan yang kuat ini dikarenakan pernyataan tersebut merupakan dasar bagi perusahaan untuk menetapkan harga jual produk disamping biaya administrasi dan laba yang diinginkan perusahaan. 
b. Hubungan yang biasa / sedang itu terjadi antara harga Rp. 110.000 Rp.150.000 dengan proses produksi, karena harga yang diberikan kepada suatu produk terkadang dilihat juga dari proses produksi yang dilakukan. Semakin lama proses produksi maka mempengaruhi terhadap biaya yang akan dikeluarkan perusahaan dan akan mempengaruhi harga dari produk itu sendiri.

c. Hubungan yang lemah itu terjadi antara harga Rp. 110.000 - Rp. 150.000 dengan keindahan produk. Karena harga tidak selalu mempengaruhi indah atau tidaknya suatu produk.

4. Hubungan Timbal Balik Antar How's, sebagai contoh untuk biaya produksi memiliki hubungan kuat dengan jenis bahan, hal ini dikarenakan jenis bahan yang digunakan dalam membuat sepatu perawat sangat mempengaruhi biaya produksi. Contoh hubungan yang sedang yaitu antara biaya produksi dengan jenis bahan, hal ini dikarenakan jenis bahan yang digunakan merupakan bagian dari biaya yang harus dikeluarkan perusahaan. Sedangkan untuk karakteristik yang berhubungan lemah contohnya adalah proses produksi dengan keindahan produk.

5. Penilaian Pesaing, dalam penelitian ini, produk yang menjadi pesaing $\mathrm{CV}$. $\mathrm{X}$ (Pembuat Sepatu) adalah CV. Y (Pesaing). Karena CV. X dan CV. Y memproduksi produk yang sama.

a.Penilaian Pesaing Pelanggan, dari hasil penilaian pesaing pelanggan, dapat dilihat bahwa penilaian pelanggan terhadap sepatu perawat yang diproduksi oleh CV. X dan pesaingnya tidak terlalu jauh berbeda. Ada variabel - variabel tertentu CV. X lebih unggul dari perusahaan pesaing dan begitu pula sebaliknya. b. Penilaian Pesaing Teknis, dari hasil penilaian pesaing teknis, dapat dilihat bahwa penilaian yang diberikan oleh pihak internal / karyawan perusahaan tentang deskripsi teknis CV. X dan pesaingnya terlihat berbeda.Setiap merek sepatu memiliki keunggulan dan kelemahan sendiri pada produknya.

6. Prioritas Persyaratan Pelanggan / Konsumen. Dalam menganalisis prioritas persyaratan pelanggan ada beberapa hal yang akan dianalisis yaitu :

a. Tingkat kepentingan konsumen, dari derajat kepentingan yang paling tinggi adalah harga dengan nilai derajat kepentingan 10 .

b. Nilai target, nilai target yang paling tinggi yaitu 8 dilakukan pada harga Rp. 110.000 - Rp.150.000, tinggi hak $3 \mathrm{~cm}-5 \mathrm{~cm}$, model hak flat, bahan dasar nyaman, kaki tidak lecet dan mudah untuk diperoleh. Karena perusahaan ingin lebih berinovasi pada produknya dengan memperhatikan semua aspek untuk membuat produk menjadi lebih unggul.

c. Faktor skala dari hasil perhitungan faktor skala, nilai faktor skala tertinggi terdapat pada kaki tidak lecet dan mudah untuk diperoleh. Hal ini menunjukkan bahwa sepatu yang aman saat digunakan serta pemasarannya yang baik sangat diperlukan, agar konsumen nyaman saat menggunakan sepatu dan tidak butuh waktu lama saat membeli sepatu. Cukup dengan menelepon tanpa harus datang ke toko atau ketempat produksi mereka dapat membeli sepatu.

d. Poin penjualan, dalam penelitian ini untuk nilai poin penjualan yang digunakan bernilai 1, 1,2 dan 1.5. Karena untuk nilai 1 menunjukkan persyaratan pelanggan tersebut penjualan rendah (kurang 
berpengaruh), untuk nilai 1,2 menunjukkan penjualan sedang (sedikit berpengaruh) dan nilai 1.5 menunjukkan penjualan lumayan tinggi (berpengaruh) terhadap peningkatan perencanaan produk, bahwa persyaratan konsumen yang berpengaruh terhadap peningkatan kualitas produk adalah yang memiliki nilai poin penjualan 1.5 yaitu harga Rp. 110.000 - Rp. 150.000, bahan nyaman dan kaki tidak lecet. Hal ini dikarenakan persyaratan konsumen tersebut sangat menentukan bagi konsumen dalam mendapatkan kualitas produk yang baik dan sebagai persyaratan yang dibutuhkan oleh konsumen dan bobot absolut.

7. Dari hasil perhitungan bobot absolut, diperoleh nilai bobot absolut dari yang tertinggi adalah harga, dan yang terendah pada variabel hak sepatu tidak mudah lepas. Prioritas Deskripsi Teknis, dalam menganalisis prioritas deskripsi teknis, ada beberapa hal yang akan dianalisis yaitu :

a. Tingkat Kepentingan Teknis, Nilai paling tinggi untuk tingkat kepentingan deskripsi teknis yaitu biaya produksi, karena merupakan hal yang utama dalam kegiatan produksi untuk dapat menentukan harga jual. Sedangkan untuk derajat kepentingan yang paling kecil adalah pemasaran, perusahaan menganggap tidak terlalu penting karena sudah merasa yakin dengan pemasaran yang dilakukan dan produknya.

b. Bobot Absolut, diperoleh nilai bobot absolut tertinggi yaitu jenis bahan dengan bobot 198. Hal ini menunjukkan bahwa jenis bahan harus diperhatikan agar produk yang sampai ketangan konsumen nyaman saat digunakan / tidak mengecewakan konsumen.

c. Bobot Relatif, diperoleh nilai bobot relatif tertinggi yaitu jenis bahan dengan bobot 288.15. Hal ini menunjukkan bahwa jenis bahan harus diperhatikan oleh perusahaan agar sepatu nyaman saat digunakan dan harga sepatu Rp. 110.000 - Rp. 150.000 .

\subsubsection{Pembuatan Matriks Perencanaan Komponen (Part Planning)}

Dari hasil perhitungan pada bab sebelumnya, diperoleh nilai bobot absolut terbesar yaitu pada biaya bahan baku dengan bobot sebesar 10795.02, hal ini menunjukkan bahwa bahan baku yang digunakan harus diperhatikan agar dapat menentukan harga jual dengan tepat sehingga konsumen merasa terpuaskan. Dapat dilihat pada gambar 2 di bawah ini. 


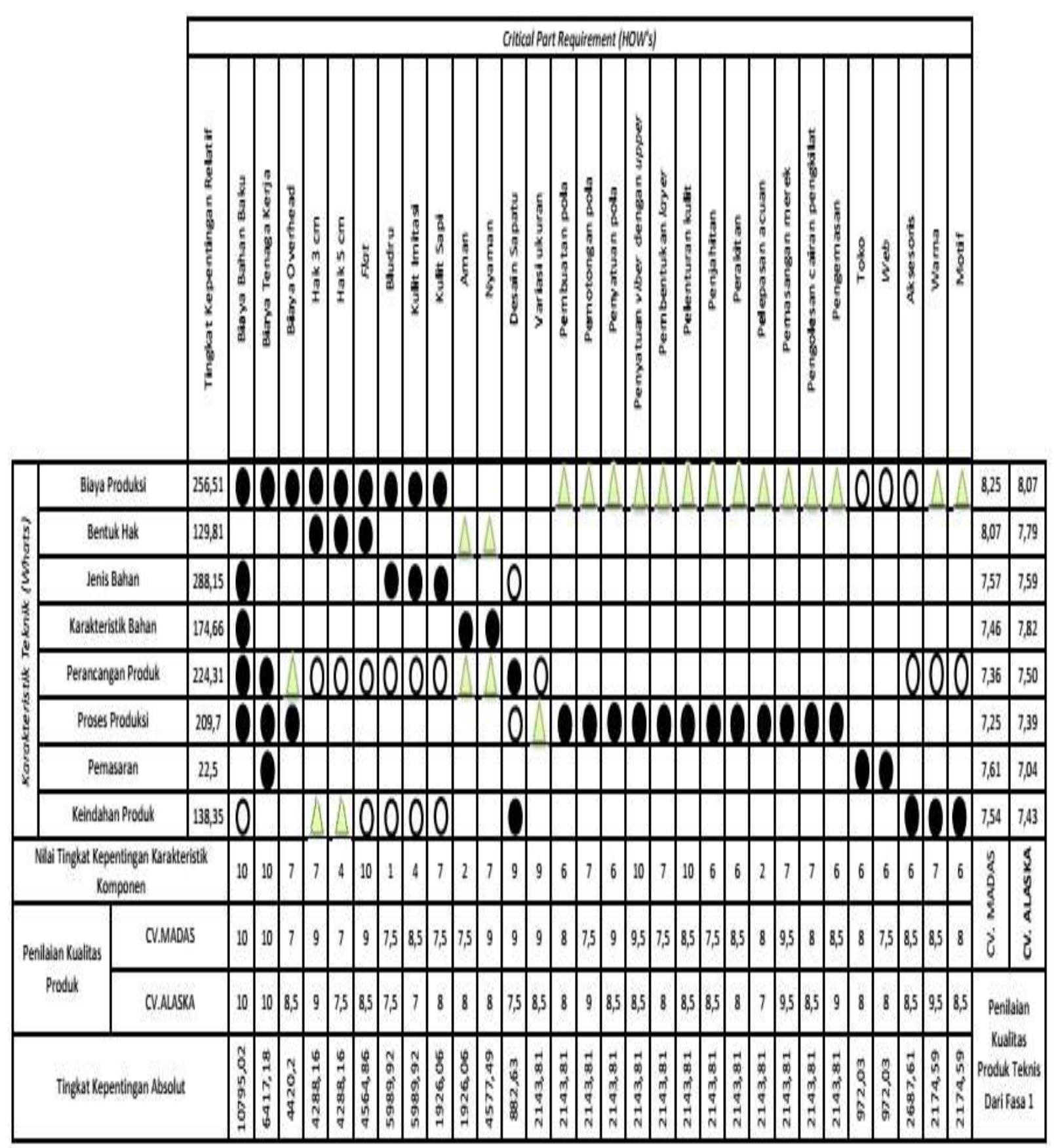

Gambar 2. Matriks Perencanaan Komponen.

\subsubsection{Matriks Perencanaan Proses}

Diperoleh nilai tingkat kepentingan absolute tertinggi pada proses persiapan dan pemeriksaan bahan baku serta peralatan. Untuk itu perusahaan harus lebih memperhatikan proses tersebut, karena pada proses persiapan dan pemeriksaan bahan baku serta peralatan merupakan proses awal yang akan menentukan baik atau tidaknya produk yang akan dihasilkan. Dapat dilihat pada gambar 3 berikut ini. 


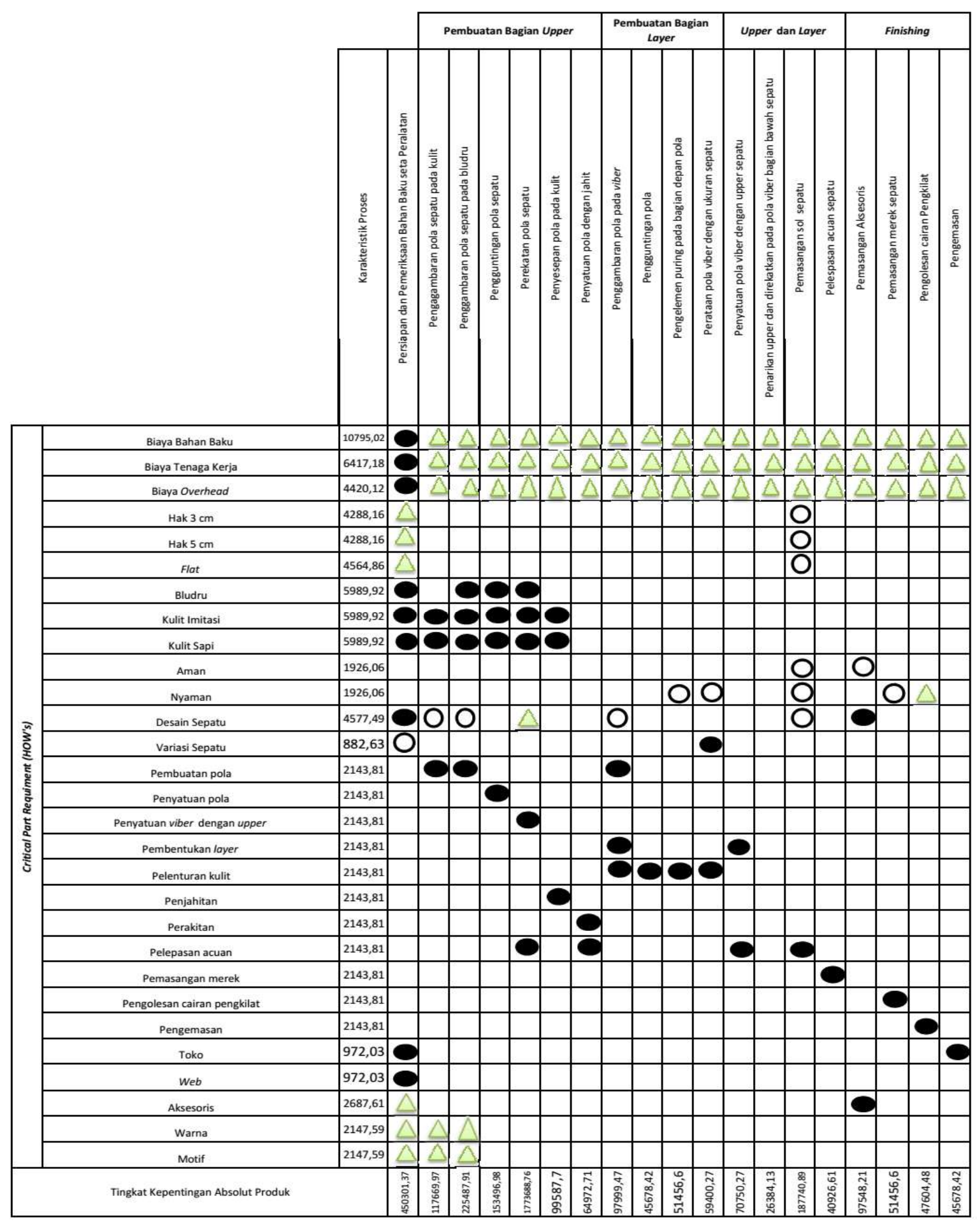

Gambar 3. Matriks Perencanaan Proses.

\subsubsection{Matriks Perencanaan Produksi}

Diperoleh nilai tingkat kepentingan absolute tertinggi pada stasiun kerja. Untuk itu perusahaan harus memperhatikan semua stasiun - stasiun kerja yang mendukung kegiatan produksi selain untuk membuat pekerja merasa nyaman saat bekerja juga dampak yang akan dirasakan oleh perusahaan adalah minimnya jumlah produk cacat yang dihasilkan bagian produksi. Dapat dilihat pada gambar 4 berikut. 


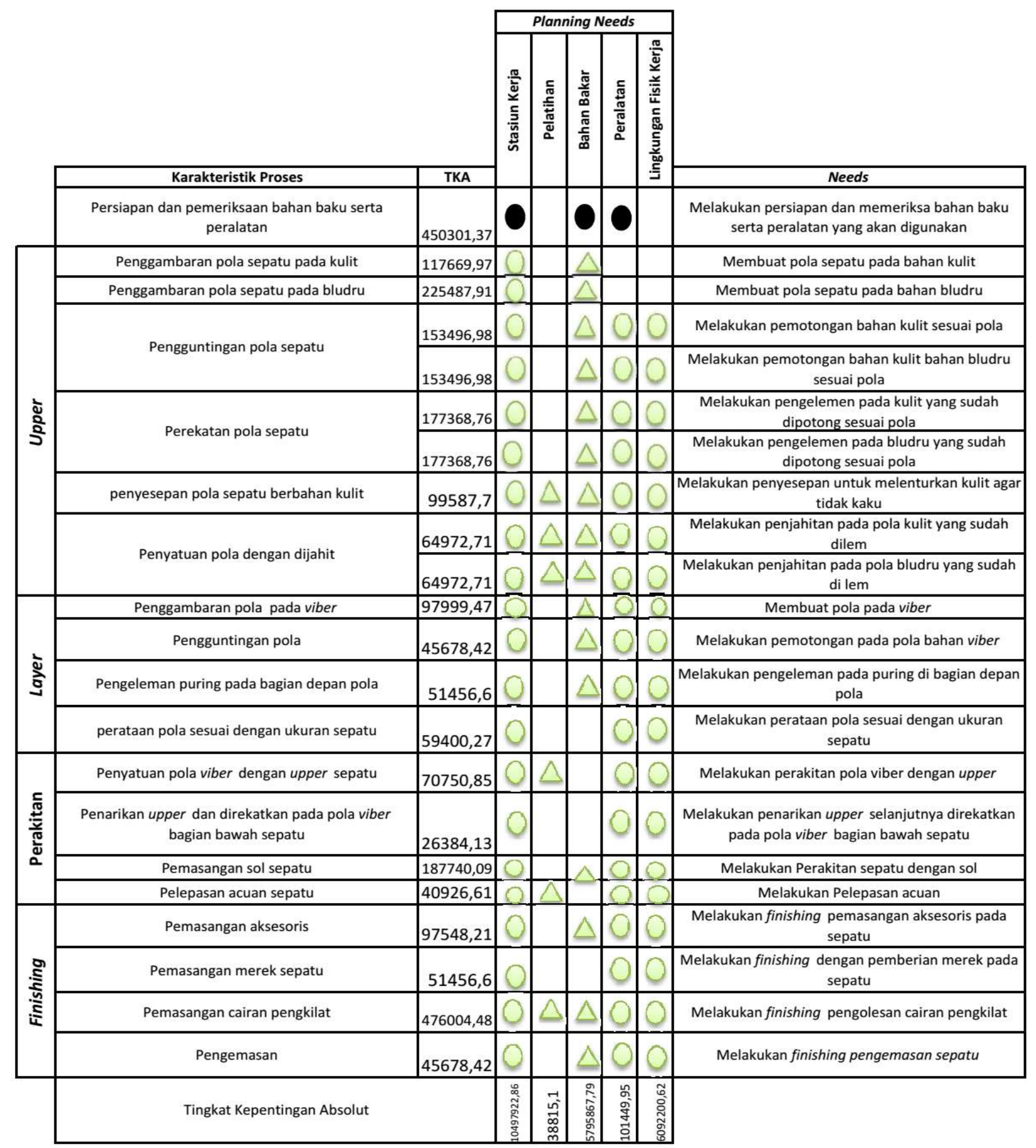

Gambar 4. Matrik Perencanaan Produksi.

Tabel 1. Perbedaan Sepatu Perawat CV. X dengan Usulan Desain

Keterangan CV.X Usulan Desain

$\begin{array}{ccc}\text { Tinggi Hak } & 3 \mathrm{~cm} & 3 \mathrm{~cm}-5 \mathrm{~cm} \\ \text { Model Hak } & \text { Flat } & \text { Flat }\end{array}$

$\begin{array}{cc}\text { Bahan } & \text { Kulit Sapi } \\ \text { Warna } & \text { Putih }\end{array}$

Kulit Sapi, Kulit Imitasi / bludru

Aksesoris

Ada asesoris

Putih dan Hitam

Tidak digunakan 


\subsubsection{Usulan Desain Produk}

Berdasarkan pengolahan data, maka diperoleh usulan desain produk sepatu perawat wanita. Pada tabel. 1 diatas ada perbedaan antara produk CV. X saat ini dengan usulan desain yang diusulkan oleh penulis. Berikut pada gambar 5 usulan desain produk.

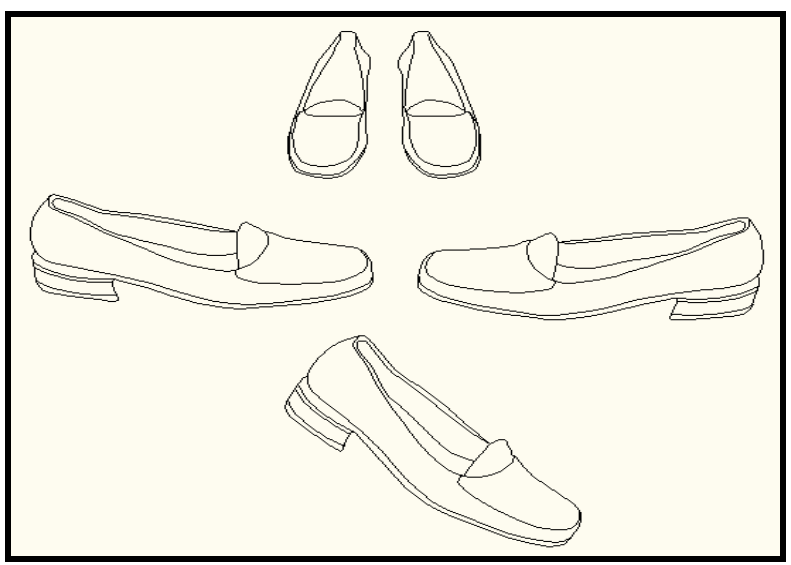

Gambar 5. Usulan Desain Sepatu Perawat.

\section{KESIMPULAN DAN SARAN \\ 5.1. Kesimpulan}

- Dari hasil penyebaran kuesioner diperoleh 16 variabel yang merupakan kebutuhan dan keinginan konsumen, yaitu :

1. Harga Rp. 110.000 - Rp. 150.000 .

2. Tinggi hak $3 \mathrm{~cm}-5 \mathrm{~cm}$.

3. Model hak Flat.

4. Bahan nyaman.

5. Tapak sepatu tidak licin.

6. Kaki tidak lecet saat menggunkan sepatu.

7. Bentuk depan lancip.

8. Bagian depan tertutup $1 / 3$ dari panjang telapak kaki.

9. Bagian belakang tertutup.

10. Tahan lama.

11. Tahan terhadap perubahan cuaca.

12. Hak sepatu tidak mudah lepas.

13. Mudah untuk diperoleh.

14. Memakai aksesoris.

15. Warna putih dan hitam.

16. Motif polos.
- Prioritas utama yang dihasilkan dari Quality Function Deployment (QFD) fasa 2 yaitu :

1. Biaya produksi lebih dipengaruhi oleh biaya bahan baku selain biaya tenaga kerja dan biaya overhead pabrik yang nantinya akan menjadi pertimbangan dalam menentukan harga jual, oleh karena itu perusahaan harus lebih memperhatikan biaya bahan baku yang merupakan biaya yang paling penting sebagai pembentuk utama dari produk.

2. Bentuk hak dipengaruhi oleh model hak serta tinggi hak sepatu perawat, oleh karena itu perusahaan harus lebih memperhatikan tinggi hak dari sepatu perawat dan bentuk haknya yang membuat konsumen nyaman serta merasa adanya inovasi dari bentuk produk.

3. Jenis bahan dipengaruhi oleh bahan dasar yang digunakan dalam membuat sepatu perawat. Untuk itu perusahaan harus memperhatikan dalam pemilihan bahan, bahan kulit sapi dan kulit imitasi dipilih untuk ketahan sepatu. Bahan kulit imitasi menjadi alternatif bila kulit sapi mengalami kelangkaan.

4. Karakteristik bahan dipengaruhi oleh keamanan yang dirasakan konsumen saat menggunakan sepatu perawat yaitu seperti tapak sepatu yang tidak licin agar konsumen yang memakai sepatu tidak terjatuh, dan kaki konsumen tidak lecet saat menggunkan sepatu. Oleh karena itu perusahaan harus memperhatikan karakteristik bahan. Seperti bahan didalam sepatu tidak keras, sol sepatu tidak licin.

5. Perancangan produk dipengaruhi oleh bentuk depan sepatu lancip, bagian depan sepatu tertutup $1 / 3$ dari panjang kaki serta bagian belakang sepatu tertutup. Oleh karena itu perusahaan harus memperhatikan 
desain sepatu mulai dari depan sampai belakang agar sepatu memberikan daya tarik pelanggan untuk membeli.

6. Proses produksi dipengaruhi oleh tahan lama atau tidaknya sepatu, ketahanan sepatu menghadapi perubahan cuaca serta hak sepatu tidak mudah lepas. Oleh karena itu perusahaan harus memperhatikan hal - hal tersebut agar produk dapat berumur panjang.

7. Pemasaran dipengaruhi oleh mudahnya produk untuk diperoleh. Oleh karena itu perusahaan harus memperhatikan strategi pemasaran yang dilakukan perusahaan.

8. Keindahan produk dipengaruhi oleh penggunaan aksesoris pada sepatu, warna pada sepatu serta motifnya. Untuk itu perusahaan harus memperhatikan estetika dari produk yang diproduksinya, agar konsumen tertarik untuk membeli.

- Berdasarkan informasi yang diperoleh dari matriks perencanaan proses atau fasa 3 dari Quality Function Deployment (QFD), maka dilakukan upaya pengembangan yang sesuai pada prioritas yang ingin dicapai. Berikut adalah 5 (lima) proses yang harus diperhatikan oleh Perusahaan dalam pembuatan sepatu perawat yaitu :

1. Persiapan dan pemeriksaan bahan baku serta peralatan, tahap ini merupakan tahap awal dalam pembuatan sepatu perawat.

2. Penggambaran pola sepatu pada kulit dan bludru akan berbeda. Untuk itu perusahaan harus memperhatikan proses ini.

3. Pemasangan sol sepatu, proses ini harus diperhatikan karena dapat menentukan keamanan dan kenyamanan saat menggunakan sepatu.

4. Perekatan pola sepatu, hal ini berhubungan dengan keindahan dan ketahanan sepatu. Jika perekatan pola sepatu tidak rapi akan mengurangi nilai jual sepatu dan jika perekatan pola sepatu tidak dilakukan dengan baik akan membuat sepatu tidak tahan lama.

5. Pengguntingan pola, proses ini akan mempengaruhi bentuk dan keindahan sepatu.

- Berdasarkan informasi yang diperoleh dari matriks perencanaan produksi atau fasa 4 dari Quality Function Deployment (QFD), maka dilakukan upaya pengembangan yang sesuai pada prioritas yang ingin dicapai. Pada pengolahan data yang dilakukan pada bab sebelumnya dapat disimpulkan :

- Perusahaan harus lebih memperhatikan stasiun-stasiun kerja yang mendukung berlangsungnya proses produksi agar produk yang dihasilkan dapat sesuai dengan standar-standar perusahaan serta sesuai dengan keinginan dan kebutuhan konsumen.

- Perusahaan harus memperhatikan peralatan - peralatan yang mendukung proses produksi agar tidak terjadi gangguan pada lantai produksi. Seperti : terhentinya proses produksi karena rusaknya mesin jahit sehingga membuat terlambatnya produk dihasilkan serta pekerjapekerja yang menganggur akibat terhentinya proses produksi.

- Perusahaan harus memperhatikan lingkungan fisik kerja yang menunjang berlangsungnya proses produksi. Dengan lingkungan kerja yang nyaman membuat pekerja dapat bekerja secara optimal sehingga mempengaruhi baiknya produk yang akan dihasilkan.

- Perusahaan juga harus memperhatikan jumlah ketersediaan bahan baku di gudang. Karena ketersediaan bahan baku digudang penyimpanan akan mempengaruhi 
jalannya proses produksi. Jika bahan baku tidak ada atau dating terlambat dari yang seharusnya dijadwalkan atau bahkan terlambat dipesan maka semua proses atau tahapan produksi tidak dapat dilakukan. Hal ini akan berimbas pada pekerja yang menganggur serta ketersediaan barang jadi digudang untuk memenuhi permintaan pasar.

- Perusahaan juga sebaiknya memperhatikan pelatihan yang diberikan pada pekerja-pekerja yang dipekerjakan. Karena ada pekerjaanpekerjaan tertentu yang harus dilakukan oleh pekerja yang terlatih. Misalnya pada proses penjahitan pola sepatu, jika tidak memiliki keterampilan dalam menjahit maka perusahaan akan mengalami kerugian karena produk yang dihasilkan pada tahap ini tidak sesuai standar perusahaan.

- Pada usulan desain produk, maka penulis mengusulkan desain sepatu perawat sebagai berikut :

- Bahan dasar yang digunakan adalah kulit sapi dan kulit imitasi, karena bahan dasar yang digunakan akan mempengaruhi ketahanan produk. Kulit imitasi menjadi bahan dasar alternatif bila terjadi kelangkahan pada kulit sapi.

- Bentuk depan sepatu lancip dengan belakang sepatu tertutup serta bagian depan yang tertutup $1 / 3$ dari panjang telapak kaki. Desain ini diambil berdasarkan keinginan dan kebutuhan konsumen.
- Model hak flat, karena perawat banyak melakukan gerakan-gerakan. Untuk itu digunakan model hak flat agar perawat dapat bekerja dengan nyaman tidak merasakan sakit pada kaki.

- Tinggi hak sepatu $3 \mathrm{~cm}-5 \mathrm{~cm}$, hak sepatu dibuat bervariasi hal ini dikarenakan konsumen memiliki kebutuhan dan ketertarikan terhadap sepatu berbeda-beda. Agar konsumen nyaman saat menggunakan sepatu ini dan merasa puas terhadap produk yang mereka beli.

- Warna sepatu dibuat putih dan hitam.

- Tapak sepatu berlapiskan bahan karet agar sepatu tidak licin.

- Sepatu tidak bermotif / polos.

- Sepatu tidak menggunakan aksesoris.

\subsection{Saran}

Adapun saran - saran yang dapat disampaikan adalah :

a. Dilakukan kajian dan evaluasi lebih menyeluruh terhadap rancangan sepatu yang diusulkan.

b. Dilakukan penelitian lanjutan untuk sepatu perawat laki - laki.

c. Hasil penelitian terhadap usulan pengembangan produk sepatu perawat ini diharapkan dapat dijadikan acuan bagi pihak perusahaan atau bermanfaat bagi perusahaan dalam upaya melakukan peningkatan kualitas produk demi tercapainya kepuasan konsumen. 


\section{DAFTAR PUSTAKA}

Akao, Y. Quality Function Deployment : Integrating Customer Requirements Into Product Design, Productivity Press. Portland, Oregon., 1990.

Aviasti, Dewi, Wenny. Aplication Quality Function Deployment (QFD) to Improve Quality of Services in Ngadoe Café, 2013.

Cohen L. Quality Function Development: How to Make QFD Work for You, Massachusset. Addison-Wesley Publishing Company. 1995.

Dale, B. G. Managing Quality, Edisi Kedua, Prentice Hall International, Manchester, UK, 1994.

Dewi, Iyan, Meidasari. Usulan Desain Produk sepatu Pantofel dengan Pendekatan Quality Function Deployment (QFD), 2014.

Eshan S. Jaiswal. A Case Study on Quality Function Deployment (QFD), IOSR Journal of Mechanical and Civil Engineering (IOSR-JMCE), India, 2012.

Saidani Basrah dan Arifin Samsul, Jurnal, "Pengaruh Kualitas Produk dan Kualitas Layanan Terhadap Kepuasan Konsumen dan Minat Beli pada Ranch Market”. Vol. 3, No.1, 2012.

Sulistyawati, H. Penerapan Quality Function Deployment untuk Meningkatkan Kepuasan Pelanggan di restoran Boyong Kalegan. Vol. 18, No.1, 2005.

Walpole, Ronald E. Pengantar Statistik Untuk Ilmuwan dan Insinyur, Penerbit PT. Gramedia Pustaka Utama, Jakarta, 1995.

Wijaya, T, .Manajemen Kualitas Jasa, Penerbit PT. Indeks, Jakarta, 2011.

Zeithaml, M. J. Bitner. Service Marketing, integrating customer focus across the firm. Mc Graw Hill, New York, 2008. 